insects, the bed-bug and the cockroach, under natural conditions. P. Schoorl (Bennekom) spoke on the curious way in which the rate of increase in weight of pigs fluctuates in an apparently rhythmic manner.

The second day of the conference was devoted mainly to papers dealing with the importance of rhythmic processes in medical physiology and medical practice. Communications were made by Hj. Holmgren (Stockholm), A. Jores (Hamburg), F. Gerritzen (Lunteren), J. Möllerström (Stockholm), Prof. R. Hopman (Cologne), W. Menzel (Tübïngen), II. Arborelius (Halmstad), and E. von Philipsborn (Oberstdorf). Lively discussion followed every paper.

It has been arranged that the papers given at the conference will be published in a special supplement to the Acta Medica Scandinavica. 'The future of the Society was discussed at some length. Most of its members are mammalian physiologists or practising physicians, and some zoologists and others were in doubt as to whether their work was of real interest to theso medical workers. It was almost unanimously decided that all investigators whoso problems dealt with questions of rhythmic activity would bo likely to learn a great deal from discussion of each other's work, and it was decided to make an attempt to increase the membership of the Society. It is particularly hoped that more British workers will join; further particulars may be obtained from the secretary, Dr. Hj. Holmgren, Karolinska Institutet, Stockholm.

The local arrangements for the conference were made with great efficiency by Dr. F. Gerritzen of Lunteren, and excursions, dinners, etc., were all greatly enjoyed. Members of all nationalities, including thoso which aro now unhappily at war, were able to discuss their work in a particularly friendly atmosphero.
Kenneth Mellanby.

\title{
PROBLEMS OF GROWTH AND DIFFERENTIATION
}

$\mathrm{A}^{\mathrm{T}}$

T North Truro, a small village near the extreme end of Cape Cod in Massachusetts, a remarkably successful conference on problems of growth and differentiation was held during August 7-11. Sponsored by the editorial board of Grouth, members of which also carried out the excellent local arrange. ments, it brought together about seventy workers from the fields of genetics, embryology, biochemistry, morphology, and botany. Many were accommodated in the wooden cabins of Whitman House, at the edge of a pinewood, not far from excellent sea-beaches, and the delegation from England, at any rato, appreciated to the full the hot weather and the sunshine. The meetings took place in the village school, a building in the attractive wooden New England style, admirably adapted for the purpose. Some informal discussions also took place in the Marine Biological Laboratory of the Lankenau Hospital, about half a milo away.

Each morning and afternoon began with a lecturo lasting about an hour, and followed by unhurried discussion and comment. The opening session was devoted to a lively discussion of the proper definitions of growth, differentiation and determination, following a paper on growth and cell-division by $\mathrm{Dr}$. Warren Lewis (Bar Harbor), who illustrated his points by a number of films. In the afternoon Dr. P. WV. Gregory (Berkeley) gave an account of the body of work which has shown a relationship between hereditary size in mammals and glutathione content of the tissues, though the connexion does not seem to be so clear in the case of birds. As regards its meaning, an action of sulphydryl groups on synthetically acting proteases seems the most probable hypothesis. The general connexion of $-\mathrm{SH}$ and growth or cell-division also came in for discussion.

The second day was given over to the relations between genetics and embryology. In the morning Prof. Curt Stern (Rochester) contributed a masterly description of the present position, dealing with the timo of action of genes, dependent and self-differentiation, nuclear induction, etc. He pointed out that dependent differentiation may not always be due to the diffusion of substances; but that in some cases the migration of cells themselves may be involved. Particular interest was aroused by his summary of recent work showing that, in plants also, transplantation experiments reveal nuclear inductors. In the afternoon, Dr. C. H. Waddington (Cambridge, England) took up the story in relation to Drosophila development. After making a distinction between form and matter which later gave rise to some argument, he developed the interesting fact that when in a mutant organism, an organ dovelops in the 'wrong' place, genes which normally act upon such organs can act just as well though the relation of part to whole is abnormal; or in a 'monstrous' part, such as a structure which is proximally a leg and distally an antenna, leg-genes and antenna-genes still exert their characteristic effects. The meeting closed with an animated discussion of the problem whether tho 'deployment of competences' of the English school is really the same as the "segregation of potencies' of the Americans or not.

On the third day, biochemical problems were taken up. Dr. J. Needham (Cambridge, England) described the progress which has been made during the last ten years in our knowledge of the chemical aspects of organizer phenomena. For reasons of time, the discussion was almost entirely confined to the Amphibia. The basic difficulty in these investigations, he said, which had not been at all anticipated at their beginning, is that the competent ventral ectoderm, on which alone the power of a substance to evoke neural differentiation can be tested, itself contains the natural evocator in masked or inactivated form, as can readily bo shown by denaturing its proteins in any way and implanting it into another embryo. 'That adult tissues probably all contain the primary evocator can be shown by the fact that in many cases denaturation of their proteins is not necessary. Recent work on the metabolism of the different regions of the gastrula, which should throw light on the liberation of the primary evocator, was also considered in detail. In the afternoon, the chemical aspects of later growth were described by 
Dr. Otto Glaser (Amherst) who introduced the conferenco to a new method of formulating the growth of organisms and their chemical constituents.

'Tho last full day opened with a highly stimulating paper from Dr. Schottó (Amherst) on regeneration. After briefly reviewing the old question of the origin of the material of tho regeneration blastema in invertebrates and vertebrates, ho went on to deal with the vexed but important problem of the 'toti. potency' of the regeneration blastema in Amphibia. Admitting that limb-competence in the tail-blastema or vico versa has not as yet been definitely proved, ho xent on to describo his remarkablo experiments which indicato that lens-competenco, though long absent from the body epidermis, reappears in the material of tho tail blastema. It seems also to reappear in regenerating epidermis over tho oye. Notochord implanted in tail blastema has also induced pronephric and neural tissuo. Should theso findings be further confirmed and generally received, a now word will bo needed to describo tho return of competence after its ontogenetic disappearance. From the floor of the houso the word 'recuperation' was suggested, and this seemed to find somo favour. In any ovent, as Ross Harrison has pointed out, there are undeniable instances of reversals of deter. mination, as in tunicates, so the return of competence in vertebrates would not be quito unoxpected. Tho afternoon session on this day was devoted to the studies of Dr. Sinnott (New York) on gene-controlled shape in cucurbitaceous fruits; this led to a vigorous discussion of field-concepts, which had been brewing during former sessions.

On the last morning Dr. Woodger (London) explained tho advantages which would accruo to biologists in framing their theories if use was made of logistic technique, of which he gave some examples. Ho also directed attention to certain points of interest for biological theory which had arisen during tho mectings.

On the whole, the meotings were remarkable for the degreo of unanimity of thought on funda. mental problems which provailed, as perhaps must bo the case when there is enough time to explain individual points of view in a spirit of moderation and candid sincerity. Apart from those who con. tributed lectures, the discussions were greatly enlivened by the presence of such workers as Dr. Berrill (Aontreal), Dr. Hoadloy (Harvard), Dr. 'Thimann (Harvard), Dr. Paul Weiss (Chicago), Dr. Frank Daniel (Berkeley), Dr. Barth (New York), Dr. Reimann and Dr. Hammett (Philadelphia) who showed a film illustrating differentiation and dedifferentiation in Obelia, Dr. L. C. Dunn (New York), Dr. Samuel Brody (Missouri), Dr. Hamburger (St. Louis) and Dr. Frank (New York). At the end of the conferenco suitable steps wero taken to form an organization able to call together similar conferences on growth and differentiation in futuro years.

\section{TABOO*}

$\mathrm{T}$ HE use of the word 'taboo' in anthropology for customs all over the world, which resemble in essentials the reference adopted from Polynesia, seems undesirable and inconvenient. For such customs the terms 'ritual avoidance' or 'ritual prohibition' aro proposed, defining them by reference to two fundamental concepts, 'ritual status' and 'ritual value'. A ritual prohibition is a rulo of behaviour which is associated with \& belief that an infraction will result in an undesirable chango in the ritual status of the person who fails to keep the rulo; that is, it involves the likelihood of some minor or major misfortune which will befall the person concorned.

Anything which is tho object of a ritual avoidance or taboo may be said to have ritual value. 'The ritual value is exhibited in the behaviour adopted towards the object or occasion in question-not only in the negativo ritual, but also in the positive ritual. A large class of positive rites, those of consecration or sacralization, have for their purpose to endow objects with ritual value.

Tho word 'value' as thus used always refers to a relation between a subject and an object. It may refer to the act of behaviour towards an object. A social system can bo conceived and studied as a system of values. A society cannot oxist except on a basis of a certain measure of similarity in the interests of its members. In terms of values the first necessary condition of the existenco of a society is that the individual members should agreo in some

- From the Frazcr Lecture, 1939, bs Prof. A. R. Radeliffe-Bronn. Cambridge: At the University Press, 1939. Pp. 49. 2s. Od. net.) measure on the values that they recognize. To avoid misunderstanding it is necessary to add that a social system also requires that persons should bo objects of interest to others.

The study of ritual may bo approached by the consideration of the purpose or reasons for the rite, or by a consideration of its meaning. A third method is by consideration of the effects - the direct effect on the person concerned, which may be termed the psychological effect, and the secondary effect on the social structure, the network of social relations binding individuals together in an ordered lifo-the social effect. By consideration of theso wo may succeed in defining the psychological function, and in discovering the social function of a rite.

The rites are readily perceived to be symbolic. The immediato psychological effect can to some extent bo observed by watching and talking to the performers. The ostensible purposo is present in their minds, but so also is that complox set of cosmological beliefs by reference to which the rito has a meaning. In the performance of the rite the native has mado a con. tribution to the maintenance of the order of the universe, of which man and Nature are the interdependent parts.

Assuming that the act is symbolic, what method, other than that of guessing, is there of arriving at its meaning ? Wo may start with a general working hypothesis that when in a single society the same symbol is used in different contexts, or on different kinds of occasions, thero is a common element or meaning, and that by comparing the various uses of the symbol we may be able to discover what the 